\title{
Pengaruh Penggunaan Media Pembelajaran Pengenalan Hewan Mamalia Laut Berbasis Virtual Reality Terhadap Prestasi Belajar Anak Kelompok B di TK Negeri Banjar
}

\author{
Made Tia Dwariani $^{1}$, Nyoman Sugihartini ${ }^{2}$, Gede Saindra Santyadiputra ${ }^{3}$ \\ ${ }^{123}$ Pendidikan Teknik Informatika, Universitas Pendidikan Ganesha Singaraja-Bali, Indonesia
}

\author{
A R T I C L E I N F O \\ Article history: \\ Received 19 January 2020 \\ Received in revised form \\ 10 February 2020 \\ Accepted 12 March 2020 \\ Available online 25 April \\ 2020 \\ Kata Kunci: \\ Virtual Reality, Prestasi \\ Belajar, Respon Siswa \\ Keywords: \\ Virtual Reality, Learning \\ Achievement, Student \\ Responses.
}

\begin{abstract}
A B S T R A K
Penelitian ini bertujuan untuk mengetahui (1) perbedaan prestasi antara anak yang belajar menggunakan media Virtual Reality dan anak yang belajar menggunakan LKA (Lembar Kerja Anak) di TK Negeri Banjar, (2) respon anak setelah menggunakan media Virtual Reality pada tema binatang. Jenis penelitian ini adalah penelitian eksperimen dengan desain Post Test Only Control Group Design. Populasi penelitian mencakup seluruh anak kelompok B yang berada di TK Negeri Banjar. Sampel penelitian yang digunakan yaitu kelompok B1 sebagai kelompok kontrol dan kelompok B2 sebagai kelompok eksperimen dengan jumlah sampel 32 orang. Teknik pengumpulan data yang digunakan yaitu tes, observasi, dan dokumentasi. Data prestasi belajar dianalisis melalui uji prasyarat yaitu uji normalitas dan uji homogenitas dengan hasil kedua kelompok berdistribusi normal dan homogen, dilanjutkan dengan uji hipotesis yang menggunakan uji t.
\end{abstract} Hasil penelitian menunjukkan bahwa (1) terdapat perbedaan yang signifikan skor rata-rata siswa pada tema pengenalan binatang mamalia laut anak yang menggunakan Media Virtual Reality dengan tanpa menggunakan media Virtual Reality pada anak kelompok B di TK Negeri Banjar. Hasil analisis uji-t memperolej thitung 3,968 yang lebih besar dari ttabel 2,359. Berdasarkan kriteria pengujian ini berarti H0 ditolak, (2) respon anak terhadap media Pengenalan hewan mamalia laut didapat persentase hasil angket respon siswa adalah $82,5 \%$ yang tergolong dalam kategori sangat efektif.

\section{A B S T R A C T}

This study aims to determine (1) differences in achievement between children who learn to use Virtual Reality media and children who learn to use LKA (Children's Worksheets) in Banjar Kindergarten, (2) children's responses after using Virtual Reality media on animal themes. This type of research is experimental research with Post Test Only Control Group Design. The study population included all group B children in the Banjar Kindergarten. The research sample used was group B1 as the control group and group B2 as the experimental group with a sample of 32 people. Data collection techniques used are tests, observations, and documentation. Learning achievement data were analyzed through prerequisite tests namely normality and homogeneity tests with the results of both normal and homogeneous distribution groups, followed by hypothesis testing using the t test. The results showed that (1) there was a significant difference in the average score of students on the theme of the introduction of children's marine mammals using Virtual Reality Media without using Virtual Reality media in group B children in Banjar Kindergarten. The results of t-test analysis obtained tcount 3,968 which is greater than ttable 2,359. Based on these testing criteria, it means that $\mathrm{HO}$ is rejected, (2) the child's response to the media. The introduction of marine mammals obtained the percentage of student questionnaire responses was $82.5 \%$, which was classified as very effective.

\footnotetext{
Corresponding author.

E-mail addresses: dwarianitia@gmail.com (Made Tia Dwariani)
} 


\section{Pendahuluan}

Anak usia dini diartikan sebagai sosok individu kecil yang tengah tumbuh dan berkembang pesat baik secara fisik maupun psikologinya. Taman Kanak-kanak (TK) merupakan pendidikan formal untuk anak usia dini. Pendidikan ini berkonsentrasi pada anak usia 4-6 tahun, terbagi lagi menjadi dua kelompok, kelompok A untuk anak usia dini 4-5 tahun dan kelompok B untuk anak usia 5-6 tahun. Pada dasarnya, anak pada usia dini merupakan individu yang unik, anak mempunyai rasa ingin tahu yang tinggi terhadap lingkungan sekitar, akan diperlukan motivasi agar anak bertahan pada kegiatan tersebut dapat tercapai dengan optimal [1].

Media pembelajaran adalah sarana fisik untuk menyampaikan isi atau materi pembelajaran seperti buku, film, video dan sebagainya. Media pembelajaran adalah segala sesuatu yang dapat digunakan untuk menyalurkan pesan dari pengirim ke penerima pesan. Dalam hal ini adalah proses merangsang pikiran, perasaan, perhatian, dan minat serta perhatian siswa sehingga proses belajar dapat terjalin [2]. Namun harus dipertimbangkan juga media pembelajaran yang akan digunakan dalam pembelajaran di TK.

Standar kompetensi TK (Taman Kanak-kanak) yang tercantum dalam tujuan pendidikan di TK (Taman Kanak-kanak) membantu mengembangkan berbagai potensi anak, baik psikis dan fisik yang meliputi moral dan nilai agama, sosial, emosional, kognitif, Bahasa, seni, dan fisik motoric. Berbagai potensi itu dikembangkan melalui kegiatan yang beraneka ragam dan dijadikan sebagai bahan pembelajaran di TK (Taman Kanak-kanak). Kegiatan pembelajaran di TK (Taman Kanak-kanak) pada umumnya dikemas agar anak tertarik, sehingga anak dapat mengembangkan potensi yang dimiliki [3]. Selain itu, teknologi informasi sangat tepat untuk anak usia dini karena dapat memasukkan unsur warna, music, atau gambar berbentuk animasi yang sesuai dengan kesukaan anak, sehingga minat belajar anak akan meningkat dan tidak bosan untuk mengulangi pembelajaran [4].

Berdasarkan hasil wawancara (Terlampir) pada observasi awal yang dilakukan di TK Negeri Banjar pada kegiatan observasi awal dengan Kepala Sekolah TK Negeri Banjar yang menyatakan bahwa dalam proses belajar mengajar di kelas khusunya dalam pengenalan hewan guru hanya memanfaatkan media pebelajaran gambar, papan tulis dan buku gambar untuk mewarnai dan belum ada pemanfaatan IT di dalamnya. Selain itu siswa memiliki kemampuan memahami dan daya tangkap dalam pembelajaran itu berbeda-beda, ada yang cepat memahami dan ada yang lambat. Melihat dari permasalahan tersebut maka dari itu peneliti bermaksud menggunakan media pembelajaran Virtual Reality pengenalan hewan untuk diuji cobakan dan mencari tahu apakah media pembelajaran menggunakan media Virtual Reality berpengaruh terhadap prestasi anak di TK Negeri Banjar.

Pemilihan media pembelajaran Virtual Reality hewan mamalia laut yang dikembangkan oleh Ayu Cahya, sebagai media pembelajaran pengenalan hewan mamalia laut karena aplikasi ini memiliki fiturfitur menarik seperti mampu menampilkan hewan-hewan laut dalam bentuk animasi 3 dimensi, mampu mengelola video dengan bantuan button-button yang sudah disediakan oleh aplikasi, mampu mengeluarkan suara/narasi dan mengajak siswa merasakan langsung suasana di dalam laut. Selain menggunakan media pembelajaran yang dapat diaplikasikan dalam proses pembelajaran hendaknya juga menggunakan model pembelajaran untuk mempermudah proses penggunaan media pembelajaran. Model pembelajaran yang digunakan untuk menunjang penggunaan media pembelajaran yaitu dengan model pembelajaran area. Model pembelajaran area adalah pola pembelajaran yang dilakukan pendidik (guru) bersama sekelompok peserta didik dalam kelas secara bersamaan dengan aktivitas dan waktu yang sama pula [5].

Berdasarkan uraian latar belakang dapat dirumuskan permasalahan untuk dicari solusinya adalah sebagai berikut: (1) perbedaan prestasi antara anak yang belajar menggunakan media Virtual Reality dan anak yang belajar menggunakan LKA (Lembar Kerja Anak) di TK Negeri Banjar? (2) Bagaimana respon anak setelah menggunakan media Virtual Reality pada tema binatang?.

Berdasarkan rumusan masalah yang diuraikan diatas, tujuan penelitian ini adalah: (1) Untuk mengetahui perbedaan prestasi antara anak yang belajar menggunakan media Virtual Reality dan anak yang belajar menggunakan LKA (Lembar Kerja Anak) di TK Negeri Banjar (2) Untuk mengetahui respon anak setelah menggunakan media Virtual Reality pada tema binatang.

Hasil penelitian diharapkan dapat memberikan manfaat positif dalam penggunaan media pembelajaran. Adapun manfaat dari penelitian ini (1) manfaat teoritis yaitu pada penelitian ini diharapkan mampu menambah pengetahuan, serta dapat mengimplementasikan teori-teori yang didapat selama perkuliahan. (2) manfaat praktis yaitu pada penelitian ini diharapkan dapat memberikan pengetahuan dan pengalaman belajar baru kepada guru dan siswa, dapat memberikan kontribusi kepada sekolah dalam upaya meningkatkan kualitas pendidikan belajar siswa melalui media Virtual Reality pada tema pengenalan hewan mamalia laut dalam kegiatan pembelajaran, serta diharapkan dapat menambah pengetahuan peneliti dalam berbagai hal khusus mengenai penerapan media Virtual Reality pada tema 
pengenalan hewan mamalia laut.dengan cara menggunakan smartphone yang memiliki sensor gvroscope dengan Google Cardboard [3].

\section{Metode}

Penelitian ini merupakan penelitian eksperimen, mengingat tidak semua variabel atau gejala yang muncul dan kondisi eksperimen dapat diatur dan dikontrol secara ketat, maka penlelitian ini dikategorikan penelitian eksperimen semu (quasi experiment) [6]. Penelitian eksperimen ini memiliki tujuan untuk mengetahui perbedaan pengaruh penggunaan media pembelajaran Virtual Reality dengan pembelajaran tanpa menggunakan media pembelajaran Virtual Reality pada tema pengenalan Binatang di TK Negeri Banjar. Desain penelitian yang digunakan adalah post-test only control group design. Desain penelitian ini dipilih karena penelitian ingin mengukur prestasi anak sesudah perlakuan. Sesuai dengan gambar di bawah dalam desain penelitian ini terdapat dua kelompok yang masing-masing dipilih secara random. Kelompok pertama di beri perlakuan dan kelompok yang lain tidak diberi perlakuan.

Tabel 1. Desain Rancangan Penelitian

\begin{tabular}{lll}
\hline Kelas & Treatment & Posttest \\
\hline Eksperimen & $\mathrm{X}$ & $\mathrm{O}_{1}$ \\
Kontrol & - & $\mathrm{O}_{2}$ \\
\hline
\end{tabular}

Sampel adalah bagian dari jumlah dan karakteristik yang dimiliki oleh populasi tersebut. Teknik pengambilan sampel dalam penelitian ini yaitu dengan cara simple random sampling. Cara ini dipilih karena sulit mengubah kelompok yang sudah terbentuk. Kelompok dipilih sebagaimana telah terbentuk tanpa campur tangan peneliti sehingga kemungkinan pengaruh-pengaruh dari keadaan subjek mengetahui dirinya dilibatkan dalam eksperimen dapat dikurangi sehingga penelitian ini benar-benar menggambarkan pengaruh perlakuan yang diberikan. Cara untuk menentukan bahwa kelompok yang akan dipakai itu setara maka dapat dilihat dari nilai rata-rata kelompok. Untuk menunjukkan bahwa kedua kelompok tersebut setara, maka dapat juga dilakukan pengujian dengan menggunakan uji-t. Uji-t untuk sampel yang tidak berkorelasi atau terpisah terdiri dari dua jenis rumus, yaitu separated varians

dan polled varian. Didalam penelitian ini menggunakan 2 variabel, yaitu yaitu variabel bebas dan variabel terikat, variabel bebas dalam penelitian ini adalah media Virtual Reality, variabel terikat pada penelitian ini yaitu prestasi anak kelompok B di TK Negeri Banjar.

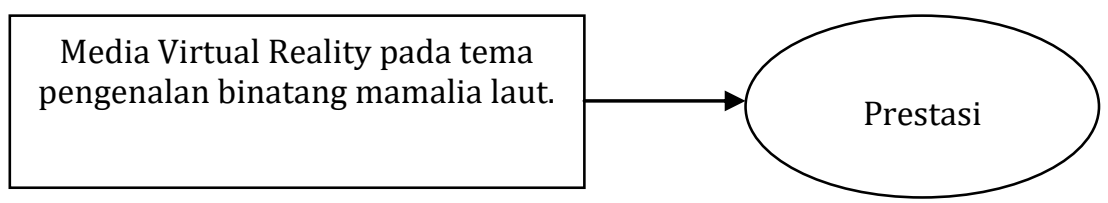

Gambar 1. Diagram Hubungan Variabel Penelitian

Teknik pengumpulan data merupakan cara untuk mendapatkan data yang diperlukan dalam suatu penelitian dan akan mendukung suatu penelitian. Dalam penelitian ini, peneliti menggunakan teknik pengumpulan data

1. Test

Penelitian ini menggunakan instrument menggunakan tes pada tema pengenalan Binatang dengan sub tema binatang mamalia laut. Soal test ini berbentuk pertanyaan-pertanyaan yang di dalamnya berisi berbagai macam pertanyaan yang nantinya digunakan sebagai tes lisan.

2. Observasi

Penelitian ini menggunakan metode observasi sedangkan instrument yang digunakan dalam penelitian ini menggunakan check list (daftar cocok).

3. Dokumentasi.

Data pendukung dalam observasi berupa foto kegiatan selama aktivitas siswa dan proses kegiatan berlangsung dan juga hasil pekerjaan siswa yang berupa hasil percobaan sederhana.

Pada uji coba instrumen dilakukan uji prasyarat terhadap perangkat pembelajaran dan instrument penelitian dilakukan pengujian terlebih dahulu untuk mendapatkan gambaran secara empirik apakah perangkat dan instrument layak digunakan dalam penelitian. Instrument dikatakan sesuai jika 
instrument tersebut sudah memenuhi kriteria validasi, reliabilitas. Untuk memperoleh tujuan dari proses analisis, data terlebih dahulu dianalisis dengan menggunakan uji validitas tes dan reliabilitas tes.

Setelah data yang diperlukan telah diperoleh dan terkumpul harus dianalisis terlebih dahulu agar dapat disusun penyajian hipotesisnya dan sebagai dasar dalam penarikan kesimpulan. Teknik analisis data adalah cara yang digunakan dalam menganalisis data untuk menguji hipotesis yang diajukan. Analisis data ini digunakan untuk menyederhanakan data ke dalam bentuk yang lebih mudah dibaca serta diinterpretasikan agar dapat menjawab hipotesis yang peneliti lakukan. Metode yang dilakukan dalam penelitian ini adalah dengan menggunakan analisis deskriptif dan analisis statistik. (1) Analisis deskriptif dilakukan untuk mengetahui tinggi rendahnya kualitas dari prestasi belajar. Metode analisis deskriptif kuantitatif adalah suatu cara pengolahan data yang dilakukan dengan jalan menerapkan rumus - rumus statistik deskriptif berupa angka rata- rata (mean), median, modus dan menghitung standar deviasi. (2) Stastistik inferensial yaitu yang pertama uji prasyarat analisis seperti uji normalitas sebaran data, uji homogenitas yang kedua uji hipotesis.

Respon siswa terhadap penggunaan media Virtual Reality pengenalan hewan mamalia laut dikumpulkan dengan menggunakan lembar observasi. Lembar Observasi yang digunakan adalah skala guttman. Setiap pernyataan apabila mendapat skor tertinggi yakni 1 maka akan diproleh skor yang di harapkan dari tiap aspek ataupun skor yang diharapkan dari keseluruhan pernyataan. Skor yang diharapkan merupakan skor maksimal atau skor tertinggi dari tiap aspek apabila tiap pernyataan diberi skor 1 sehingga mencapai skor ideal.

\section{Hasil dan pembahasan}

Hasil Penelitian

Data dalam penelitian ini adalah skor prestasi belajar anak kelompok B sebagai akibat dari penggunaan media pembelajaran Virtual Reality pada kelompok eksperimen dan LKA (Lembar Kerja Anak) pada kelompok kontrol. Penelitian ini dilaksanakan 4 kali dimana 3 kali pertemuan proses belajar dan 1 kali pertemuan post-tes. Adapun yang di bahas dalam kegiatan pembelajaran di kelas yaitu pengenalan binatang.

\section{a. Deskripsi Data Hasil Post-test}

Berdasarkan data pengukuran prestasi belajar dalam sub tema pengenalan binatang terhadap 16 anak kelompok eksperimen, diproleh data distribusi frekuensi skor post-test prestasi belajar sub tema pengenalan binatang di air kelompok eksperimen, di ketahui bahwa skor tertinggi siswa adalah 18 dan skor

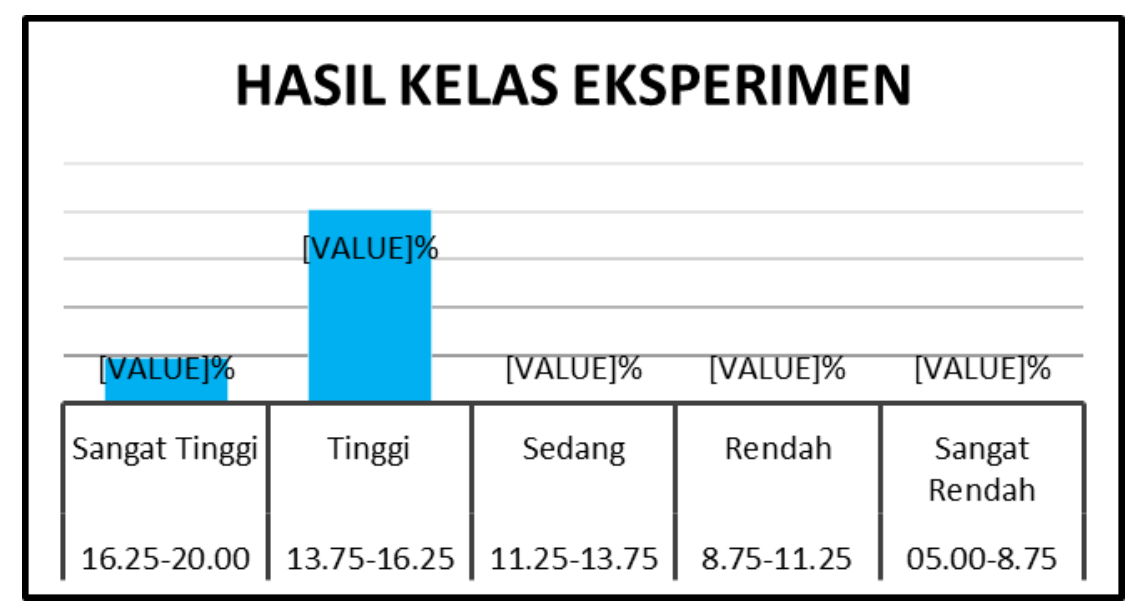

Gambar 2. Histogram Prestasi Belajar Kelompok Eksperimen

Dapat diketahui bahwa prestasi belajar Pengenalan Hewan Mamalia Laut kelas eksperimen sebanyak 18,75\% berkategori sangat tinggi dan $81,25 \%$ berkategori Tinggi serta tidak ada anak yang memiliki prestasi belajar Pengenalan Hewan Mamalia Laut berkategori sedang, rendah dan sangat rendah.

Berdasarkan data pengukuran prestasi belajar dalam sub tema pengenalan binatang terhadap 16 anak kelompok kontrol, diproleh data distribusi frekuensi skor post-test prestasi belajar sub tema pengenalan binatang di air kelompok kontrol, di ketahui bahwa skor tertinggi siswa adalah 16 dan skor terendah anak adalah10. 


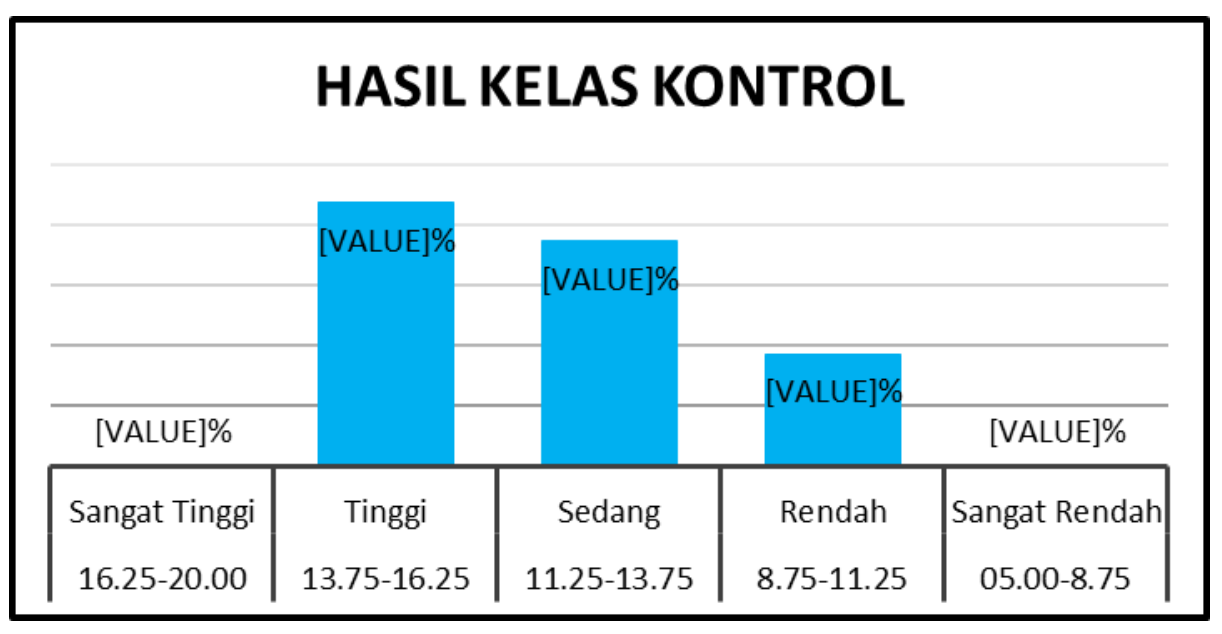

Gambar 3. Histogram Prestasi Belajar Kelompok Kontrol

Dapat diketahui bahwa prestasi belajar Pengenalan Hewan Mamalia Laut kelas kontrol sebanyak43,75\% berkategori tinggi, sebanyak 37,5\% berkategori sedang, 18,75\% berkatagori rendah dan tidak ada anak yang hasil belajarnya, sangat tinggi dan sangat rendah.

b. Uji Normalitas

Hasil uji normalitas menggunakan SPSS 16.0 menunjukkan bahwa :

Tabel 2. Hasil Uji Normalitas Kelompok Eksperimen Tests of Normality

\begin{tabular}{lllll} 
& \multirow{2}{*}{ Kelompok } & \multicolumn{3}{l}{ Kolmogorov-Smirnova $^{2}$} \\
& & Statistic & df & Sig. \\
\hline POST TEST & EKSPERIMEN & .166 & 16 & .200 \\
\hline
\end{tabular}

Uji normalitas sebaran data yang digunakan dalam penelitian ini menggunakan teknik kolmogorovsmirnov dengan bantuan SPSS 16.0. Kriteria pengujian pada taraf signifikansi 5\% yaitu apabila skor sig. > $\alpha=0,05$,maka data berdistribusi normal dan begitu pula sebaliknya apa bila skor sig. $\leq \alpha=0,05$ artinya data tidak berdistribusi normal. Skor sig. kolmogorov-smirnov pada taraf signifikan $5 \%$ untuk $n=d f=16$ adalah 0,200 sehingga skor sig. $>\alpha=0,05$ maka data skor kelas eksperimen berdistribusi normal.

Tabel 3. Hasil Uji Normalitas Kelompok Kontrol

Tests of Normality

\begin{tabular}{lllll} 
& Kelompok & \multicolumn{3}{c}{ Kolmogorov-Smirnova } \\
& & Statistic & df & Sig. \\
\hline POST TEST & KONTROL & .131 & 16 & .200 \\
\hline
\end{tabular}

Uji normalitas sebaran data yang digunakan dalam penelitian ini menggunakan teknik kolmogorovsmirnov, kriteria pengujian pada taraf signifikansi 5\% yaitu apabila skor sig. $>\alpha=0,05$, maka data berdistribusi normal dan begitu pula sebaliknya apabila skor sig. $\leq \alpha=0,05$ artinya data tidak berdistribusi normal. Skor sig. kolmogorov-smirnov pada taraf signifikan $5 \%$ untuk $\mathrm{n}=\mathrm{df}=16$ adalah 0.200 sehingga skor sig. $>\alpha=0,05$ maka data skor kelas Kontrol berdistribusi normal.

c. Uji Homogenitas Varians

Uji homogenitas dilakukan untuk menunjukkan bahwa perbedaan yang diperoleh uji-t benarbenar berasal dari perbedaan antar kelompok bukan disebabkan oleh perbedaan di dalam kelompok. Untuk menguji homogenitas varians kedua kelompok digunakan uji F sebagai berikut :

$$
F=\frac{\text { VarianTerbesar }}{\text { VarianTerkecil }}
$$




$$
\begin{aligned}
& F=\frac{3,133}{1,729} \\
& F_{\text {hitung }}=1,812
\end{aligned}
$$

Dari hasil perhitungan diperoleh $F_{\text {hitung }}=1,812$, sedangkan $F_{\text {tabel }}=2,403$. Dengan taraf signifikansi $5 \%(\alpha=0,05)$ dengan derajat kebebasan pembilang 16-1=15 dan derajat kebebasan penyebut 16-1 = 15. Maka skor $F_{\text {hitung }}=1,812<F_{\text {tabel }}=2,403$ yang disimpulkan bahwa data kedua kelompok memiliki variansi yang homogen.

\section{d. Pengujian Hipotesis Penelitian}

Berdasarkan hasil uji normalitas sebaran data dan uji homogenitas varians skor siswa dapat diketahui bahwa data yang diperoleh dari kelompok kelas eksperimen dan kelompok kelas Kontrol berdistribusi normal dan memiliki varians yang homogen. Karena data yang diperoleh telah memenuhi uji prasyarat analisis, maka uji hipotesis dapat dilakukan dengan menggunakan analisis statistic parametric dengan uji-t polled varians. Adapun kriteria pengujiannya adalah apabila harga $t_{\text {hitung }} \leq t_{\text {tabel, }}$, maka $\mathrm{H}_{\mathrm{o}}$ diterima (gagal ditolak) dan $\mathrm{H}_{\mathrm{a}}$ ditolak. Sebaliknya apabila harga $\mathrm{t}_{\text {hitung }}>\mathrm{t}_{\text {tabel }}$ maka $\mathrm{H}_{\mathrm{o}}$ ditolak dan $\mathrm{H}_{\mathrm{a}}$ diterima. Pada taraf signifikan $5 \%(\alpha=0.05)$ dengan $\mathrm{dk}=\mathrm{n}_{1}+\mathrm{n}_{2}-2$. Berdasarkan hasil analisis uji-t dari data kompetensi anak adalah sebagai berikut:

Tabel 4. Hasil Analisis Uji-t Data Skor Siswa

\begin{tabular}{lllllllll}
\hline No & Sampel & N & Dk & Mean & $\mathbf{S}^{2}$ & $\mathbf{t}_{\text {hit }}$ & $\mathbf{t}_{\text {tabel }}$ & Status \\
\hline 1 & Kelas & 16 & & 15,44 & 1,729 & & & \\
& Eksperimen & & 30 & & & 3,968 & 2,359 & $\mathrm{H}_{0}$ \\
2 & Kelas Kontrol & 16 & & 13,25 & 3,133 & & & ditolak
\end{tabular}

Berdasarkan hasil perhitungan uji-t diperoleh $t_{\text {hitung }}=3,968$, sedangkan pada taraf signifikansi $5 \%$ dengan $\mathrm{dk}=\mathrm{n}_{1}+\mathrm{n}_{2}-2=16+16-2=30$ menunjukkan skor tabel $=2,359$, sehingga diperoleh hasil analisis skor $t_{\text {hitung }}=3,968>t_{\text {tabel }}=2,359$ maka Ho ditolak dan Ha diterima. Hal ini menunjukkan terdapat perbedaan yang signifikan skor rata-rata siswa pada tema pengenalan binatang mamalia laut anak yang menggunakan Media Virtual Reality dengan tanpa menggunakan media Virtual Reality pada anak kelompok B di TK Negeri Banjar.

\section{e. Hasil Respon Anak}

Data dari hasil respon anak terhadap pengenalan hewan mamalia laut terhadap 16 anak kelompok eksperimen. Respon anak terhadap Pengenalan hewan mamalia laut yang dikumpulkan dengan kuisioner atau angket. Angket yang digunakan adalah skala Guttman dengan pilihan Iya (Y) dan Tidak (T). Dari hasil tersebut diperoleh data mengenai jumlah skor total respon anak sebesar 66. Sehingga persentase angket respon anak dapat dihitung yaitu:

$$
\begin{aligned}
\text { Persentase } & =\frac{\text { Skoryang diperoleh }}{\text { Skoryang diharapkan }} \times 100 \% \\
\text { Persentase } & =\frac{66}{80} \times 100 \% \\
\text { Persentase } & =82,5 \%
\end{aligned}
$$

Berdasarkan hasil analisis respon anak terhadap media Pengenalan hewan mamalia laut didapat persentase hasil angket respon siswa adalah 82,5\% yang tergolong dalam kategori sangat efektif. Sehingga dapat digambarkan bahwa anak sangat senang dan sangat tertarik menggunakan media tersebut, dan dapat disimpulkan penggunaan media virtual reality dalam pengenalan hewan mamalia laut efektif untuk meningkatkan prestasi belajar anak.

\section{Pembahasan}

Pada bagian ini dibahas lebih lanjut mengenai hasil penelitian yang telah diperoleh. Hasil penelitian meliputi analisis deskriptif dan analisis statistik yang mengungkap pengaruh variabel bebas terhadap variabel terikat. Variabel bebas dalam penelitian ini adalah Virtual Reality Pengenalan Hewan Mamalia Laut variabel terikat dalam penelitian ini adalah Prestasi anak terhadap kegiatan pengenalan sub tema 
binatang di air. Sebelum menentukan sampel, terlebih dahulu menentukan anggota populasi. Populasi yang digunakan pada penelitian ini adalah seluruh anak kelompok B pada tahun akademik 2019/2020 jumlah total siswa sebanyak 32 siswa. Teknik pengambilan sampel dalam penelitian ini yaitu dengan cara simple random sampling. Hasil pengundian didapatkan bahwa kelompok B1 sebagai kelas kontrol dan B2 adalah kelas Eksperimen. Kelas eksperimen adalah kelompok yang diberi perlakuan yaitu dengan media Virtual Reality, Kelas kontrol adalah kelompok siswa yang belajar tanpa menggunakan Virtual Reality. Penelitian ini dilaksanakan dalam 4 kali pertemuan, yang terdiridari 3 kali proses pembelajaran dan 1 kali pertemuan untuk posttest yang dilakukan pada kelas eksperimen dan kontrol.Setelah diberikan perlakuan, selanjutnya diberikan tes akhir pada kelas eksperimen dan kelas kontrol dengan tujuan untuk mengetahui prestasi anak setelah diberi perlakuan. Nilai maksimal ideal untuk prestasi anak adalah 20. Rata-rata prestasi pada kelompok eksperimen adalah 15,437 sedangkan rata-rata hasil belajar pada kelompok kontrol adalah 13,25. Dengan demikian, rata-rata post test prestasi belajar pengenalan hewan mamalia laut pada kelompok eksperimen lebih tinggi dibandingkan kelompok kontrol. Perhitungan normalitas, homogenitas dan uji hipotesis hasilnya tidak jauh berbeda, dimana kedua kelompok baik kelompok eksperimen maupun kelompok kontrol memiliki data yang normal yaitu tidak terdapat perbedaan. Kedua kelompok juga memiliki data yang homogeny yaitu tidak terdapat perbedaan varians antara kelompok eksperimen dan kelompok kontrol. Meningkatnya hasil yang diperoleh karena adanya kemampuan siswa itu sendiri dan variasi media pembelajaran yang digunakan dalam proses belajar. Berdasarkan uji hipotesis dapat disimpulkan bahwa perhitungan uji hipotesis dengan uji-t menggunakan Microsoft Excel 2010, dengan taraf signifikan 5\% dan derajat kebebasan 30 diperoleh thitung = 3,968 dan ttabel = 2,359. Karena thitung $>$ ttabel maka H0 ditolak dan Ha diterima. Prestasi belajar yang dipengaruhi oleh guru, cara guru dalam penyampaian materi pada saat proses belajar mengajar berlangsung. Kegiatan belajar mengajar seorang guru harus memiliki strategi agar anak didik dapat belajar secara efektif.

Secara keseluruhan penemuan yang diperoleh baik dari analisis deskriptif maupun berdasarkan hasil analisis uji-t, maka dapat diambil suatu keputusan bahwa media pembelajaran Virtual Reality pada sub tema binatang di laut memberikan pengaruh yang lebih baik dibandingkan dengan belajar tanpa menggunakan media pembelajaran Virtual Reality. Hal ini dikarenakan secara teoritik media Virtual Reality pada mata pelajaran Hewan mamalia di dalam air dan melihat hewan mamalia laut terasa lebih nyata. Melalui konten-konten yang ada pada media Virtual Reality dapat memfasilitasi anak untuk dapat meningkatkan prestasi dan aktivitas anak baik dalam pembelajaran, sehingga melalui media Virtual Reality ini anak tidak hanya terfasilitasi oleh LKA saja melainkan anak dapat langsung mersakan berada di dasar laut.

Hasil analisis respon anak terhadap penerapan media Virtual Reality berada pada kategori sangat positif. Dapat diketahui bahwa respon siswa terhadap penggunaan media pembelajaran Virtual Reality sebanyak 82,5\% yang tergolong dalam katagori sangat efektif serta tidak ada respon siswa terhadap menggunakan media Virtual Reality yang berkategori cukup efektif. Dilihat dari aspek persepsi terhadap media Virtual Reality dapat digambarkan bahwa anak senang dan tertarik menggunakan media tersebut.. Aspek cara belajar juga menunjukkan bahwa anak aktif dalam mengikuti kegiatan pembelajaran di kelas dan rasa ingin tahu anak itu ada.. Sehingga hasil angket respon ini menunjukkan bahwa belajar menggunakan media Virtual Reaity dapat diterima dengan baik oleh anak

\section{Simpulan dan saran}

Berdasarkan paparan hasil penelitian dan pembahasan dapat disimpulkan sebagai berikut : 1) Terdapat prestasi belajar yang lebih tinggi antara anak yang belajar menggunakan media Virtual Reality dan siswa yang belajar menggunakan kartu bergambar pada tema Binatang dengan subtema Pengenalan Hewan Mamalia Laut anak kelompok B TK Negeri Banjar. Dilihat rata-rata hasil belajar kelompok eksperimen dengan penerapan media Virtual Reality adalah 15,437 sedangkan rata-rata posttest untuk kelompok kontrol sebesar 13,25. 2) Hasil dari analisis respon anak dari penerapan media Virtual Reality pada tema Binatang dengan subtema Pengenalan Binatang Buas dilihat dari rata - rata skor 82,5\% yang tergolong dalam katagori sangat efektif.

\section{Daftar Rujukan}

Dewi, L. C., Arthana, I. R., \& Santyadiputra, G. S. (2018). Pengembangan Media Pembelajaran Virtual Reality Hewan Mamalia Laut. 
Dharma, K. Y., Sugihartini, N., \& Arthana, I. R. (2018). Pengaruh Penggunaan Media Virtual Reality Dengan Mode Pembelajaran Klasikal Terhadap Prestasi Siswa di TK Neger Pembina Singaraja. Jurnal Pendidikan Teknologi dan Kejuruan, 298-307.

Indra, N. F., \& Dewi, N. F. (2019). Pengaruh Media Realia Terhadap Pemahaman Anak Usia 5-7 Tahun. Jurnal Pendidikan Anak Usia Dini.

Isnaini, M., Wigati, I., \& Oktari, R. (2015). PENGARUH PENGGUNAAN MEDIA PEMBELAJARAN TORSO TERHADAP PRESTASI SISWA PADA MATERI SISTEM PENCERNAAN PADA MANUSIA DI SMP NEGERI 19. Jurnal Biota, 42-51.

Lina. (2017). Pelaksanaan Model Pembelajaaran Klasikal Di TK Kecamatan Danau Kerinci. Fakultas Keguruan Dan Ilmu Pendidikan

Melyani, N., Marwani, R., \& Yusuf, A. (2015). Studi Komparasi Metode Demonstrasi Dengan Pemberian Tugas Terhadap Kemampuan Mengenal Warna Usia 5-6 Tahun. Jurnal Pendidikan dan Pembelajaran, 4.2.

Rizal , S. (2018). Sumber dan Media Belajar Digital pada Pembeajaran Anak Usia Dini. AL HIKMAH PROC ISLAMIC EAR CHILD EDU, 201-208.

Sadiman et.al. (2005). Media Pendidikan. Jakarta: PT Raja Grafindo Persada.

Safitri, L., \& Kristanto, A. (2016). PENGARUH MEDIA MISSING FLIPCHART TERHADAP KEMAMPUAN. Paud Teratai

Suherman, w. s., Nopembri, S., \& Muktiani, N. R. (2017). Pengembangan "Majeda" Berbasis Dolanan Anak untuk Mengoptimalkan Tumbuh Kembang Siswa Taman Kanak-Kanak. Cakrawala Pendidikan, 220232.

Sugiyono. (2014). Metode Penelitian Pendidikan Pendekatan Kuantitatif, kualitatif dan R\&D. Bandung: Alfabeta.

Sukaryawan, I., Sugihartini, I., \& Pradnyana, I. A. (2019). Pengaruh Penggunaan Media Virtual Reality Terhadap Prestasi anak Kelompok B Pada Tema Pengenalan Binatang Buas. Jurnal Pendidikan Teknologi dan Kejuruan.

Swardi, Firmiana, M. E., \& Rohayati. (2014). Pengaruh Penggunaan Alat Peraga terhadap Hasil. Jurnal ALAZHAR INDONESIA SERI HUMANIORA, 297-305 